\title{
ORNAMENTAL POTENTIAL OF SWEET POTATO ACCESSIONS
}

\author{
POTENCIAL ORNAMENTAL DE ACESSOS DE BATATA-DOCE
}

\section{Rosa Maria de Deus de SOUSA ${ }^{1}$; José Ricardo PEIXOTO² ${ }^{2}$ Geovani Bernardo AMARO ${ }^{3}$; Michelle Souza VILELA ${ }^{4}$; Anne Pinheiro COSTA ${ }^{5}$; Daiane da Silva NÓBREGA ${ }^{6}$}

1. Doutoranda em Agronomia, Faculdade de Agronomia e Medicina Veterinária Campus Darcy Ribeiro -UnB. Brasília-DF, Brasil. rosamdsf@yahoo.com.br; 2. Professor, doutor em melhoramento de plantas, Faculdade de Agronomia e Medicina Veterinária Campus

Darcy Ribeiro -UnB. Brasília-DF, Brasil. peixoto@unb.br; 3. Pesquisador Doutor, Embrapa-CNPH, Brasília DF, Brasil. geovani@cnph.embrapa.br 4. Professora Doutora, Faculdade de Agronomia e Medicina Veterinária-UnB. Brasília-DF, Brasil; 5 Doutoranda em Agronomia - Faculdade de Agronomia e Medicina Veterinária Campus Darcy Ribeiro -UnB. Brasília-DF, Brasil; 6. Doutoranda em Agronomia - Faculdade de Agronomia e Medicina Veterinária-UnB. Brasília-DF, Brasil.

\begin{abstract}
Sweet potato [Ipomoea batatas (L.) Lam.] is a multipurpose plant due to the different uses for its roots, leaves, and branches. The objective of this study was to evaluate the ornamental potential of sweet potato accessions from the Germplasm Bank of Embrapa Hortaliças, Brasilia, DF, Brazil. The morphological characterization and evaluation of the ornamental potential used five accessions with distinct leaf shape (CNPH 980, CNPH 1205, CNPH 895, CNPH 796, CNPH 1284) and 12 qualitative and quantitative descriptors [plant type (PT), leaf lobe type (LLT), immature leaf color (ILC), leaf lobe number (LLN), branch color (BC), shape of central leaf lobe (SCLL), petiole pigmentation (PP), mature leaf size (MLS), mature leaf color (MLC), leaf shape (LS), branch yield (BY), and root yield (RY)]. In the evaluation of the ornamental potential, each criterion was scored from 10 (minimum) to 100 (maximum). Leaf lobe number was the trait that pleased the evaluators the most, and the greater the number of lobes, the greater was the ornamental potential. CNPH 980, CNPH 1205, and CNPH 1284 stood out for this trait. CNPH 1284 (almost divided leaf type) had the greatest score and was considered, by the evaluators, as the accession with the most harmonious aesthetics, indicating a great ornamental potential for the consumer market. All accessions studied presented considerable ornamental potential and could be used in floral arrangements or garden beds.
\end{abstract} Landscaping

KEYWORDS: Ipomoea batatas (L.) Lam. Morphological descriptors. Sweet potato leaves. Germplasm bank.

\section{INTRODUCTION}

Floriculture includes multiple forms of exploitation and cultivation, such as in the production of cut flowers, potted flowers and plants, potted and cut foliage; production of seedlings and ornamental plants in nurseries; production of bulbs, tubers and other vegetative parts (OLIVEIRA; BRAINER, 2007). In Brazil, the agribusiness segment of ornamental plants represents the consolidation of the floricultural products' trade in the domestic and foreign markets. This segment has developed into a vital action for employment and income generation in rural and urban areas, ensuring the survival of many agricultural companies (JUNQUEIRA; PEETZ, 2011).

Ipomoea batatas (L.) Lam. belongs to the family Convolvulaceae and is mainly cultivated for food purposes. In Brazil, sweet potato is an old, widely disseminated crop, primarily cultivated by small farmers, in agricultural systems with reduced inputs (HALL PHATAK, 1993; SOUZA, 2000). The species can be propagated by cuttings or seeds. Furthermore, budding can also occur when the potato is placed in a container filled with water (BACHMAN, 2003).
The species presents a great usage potential and a fast and easy growth. It adapts well to different climates and supports high temperatures (SMITH, 2007). These plants are highly desirable due to their ability to grow under varied stress conditions and for presenting few insect and disease problems. They can also cover a large space. Therefore, the existing sweet potato varieties are commonly used for landscaping (PECOTA et al., 2004) and have been widely grown for ornamental purposes in several countries (BACHMAN, 2003).

The ornamental potential of a plant should consider its ornamental morphological traits, such as flower (or inflorescence), leaf, architecture, and canopy or trunk. These traits are defined in function of one or more qualities, such as color, shape, brightness, texture, quantity, volume, and size (FISCHER, 2015). Sweet potato presents some traits of ornamental interest, including the absence of aroma, which is expected from the ornamental foliage that composes an arrangement. The lack of aroma is fundamental to avoid interference on the fragrance exhaled by the flowers that compose the arrangement (TOGNON et al., 2015).

This study aimed to evaluate the potential of sweet potato accessions from the Sweet Potato Germplasm Bank of Embrapa Hortaliças, Brasilia- 
$\mathrm{DF}$, considering their ornamental use in gardens and as cut foliages in floral arrangements, based on morphological, qualitative, and quantitative descriptors.

\section{MATERIAL AND METHODS}

\section{Plant material and site characteristics}

Field experiments were carried out at Tamanduá Farm, belonging to Embrapa Hortaliças (CNPH), located at BR-060 Km 09 (1556'31 "S and 48 $8^{\circ} 55^{\prime \prime} \mathrm{W}, 997 \mathrm{~m}$ asl), in Brasília, DF. Five sweet potato accessions (CNPH 980, CNPH 1205, CNPH 895, CNPH 796, and CNPH 1284) with different leaf shapes (cordate, triangular, hastate, almost divided, and lobed) were selected from the Sweet Potato Germplasm Bank of Embrapa Hortaliças. Three-bud cuttings were taken from these accessions and planted in polystyrene (72 cells) filled with commercial substrate. At 40 days after planting, uniform plants were selected and field transplanted at a spacing of 0.80 (between-rows) by $0.30 \mathrm{~m}$ (within-rows). The cultivar Beauregard was used as an external border for each plot. The experiment was conducted in a randomized block design, with five accessions, three plants per plot, and three replications. Plants were cultivated from September 2014 to June 2015.

At six months after planting, branches were cut, and roots were harvested. Branches and roots were then weighed to obtain their total fresh matter. Branch fresh matter and root fresh matter were determined using an analytical scale.

\section{Ornamental Potential}

Sweet potato accessions were individually evaluated by ten professionals with expertise in the Agronomy field, including researchers and landscapers. The morphological characterization was performed considering the ornamental potential of the species. Ten qualitative traits were evaluated (HUAMÁN, 1991, 1992): plant type (PT), leaf lobe type (LLT), immature leaf color (ILC), leaf lobe number (LLN), branch color (BC), shape of central leaf lobe (SCLL), petiole pigmentation (PP), mature leaf size (MLS), mature leaf color (MLC), and leaf shape (LS). Branch yield (BY; Kg) and root yield $(\mathrm{RY} ; \mathrm{Kg}$ ) were also recorded.

The ornamental potential was given as the mean of the scores assigned for each criterion evaluated, based on a methodology that considers qualitative and quantitative traits of ornamental importance to the consumer market. Each criterion was scored from 10 (minimum) to 100 (maximum), in the following categories: A) above 70 points: high ornamental potential; B) from 50 to 69 points: average ornamental potential; C) from 25 to 49 points: low ornamental potential; D) less than 25 : minimal ornamental potential (adapted from STUMPF et al., 2007).

\section{Statistical analysis}

Data were analyzed using the statistical program ASSISTAT version 7.7 beta (2016) to perform the ANOVA and Tukey's test. Treatments were considered as statistically significant at 5\% level $(\mathrm{p} \leq 0.05)$.

\section{RESULTS AND DISCUSSION}

Halcomb et al. (1977) state that the morphological characterization of accessions from a germplasm bank is usually the most accessible method to understand the existing genetic diversity and suggest the best use for this material. In this study, differences among accessions were observed for all traits ( $\mathrm{P} \leq 0.05)$, except for plant type (table 1). All accessions presented a spreading plant type. CNPH 1205 and CNPH 796 had slight leaf lobe type, whereas CNPH 895, CNPH 980, and CNPH 1284 showed moderate, deep, and very deep leaf lobe types, respectively (table 1).

Mature and immature leaf colors, branch color, shape of central leaf lobe, and petiole pigmentation are essential morphological descriptors since they identify accessions with ornamental potential. Accessions CNPH 980, CNPH 796, and CNPH 1284 presented mostly purple immature leaves, while CNPH 895 and CNPH 1205 showed slightly purple and yellow-green immature leaves, respectively (table 1 ).

The use of sweet potato for ornamentation could be facilitated by the knowledge of branch and mature leaf colors. Branches from accession CNPH 980 were mostly purple, while those from CNPH 1284 presented mostly dark purple branches. Accession CNPH 1205 had green branches, whereas CNPH 895 and CNPH 796 showed green branches with a few purple spots (table 1). Three accessions showed yellow-green mature leaves (CNPH 1205, CNPH 895, and CNPH 796). CNPH 980, which obtained the highest score for mature leaf color, presented green leaves with purple veins on the upper surface. The second highest score was recorded for $\mathrm{CNPH}$ 1284, which showed green leaves with purple edges (table 1). 
Table 1. Morphological characterization of sweet potato (Ipomoea batatas (L.) Lam.) accessions from the Germplasm Bank of Embrapa Hortaliças. Brasília-DF, Brazil, 2017.

\begin{tabular}{|c|c|c|c|c|c|c|c|c|c|c|c|c|}
\hline Accession & PT & LLT & ILC & LLN & $\mathrm{BC}$ & SCLL & PP & MLS & MLC & LS & $\mathrm{BY}\left(\mathrm{t} \mathrm{ha}^{-1}\right)$ & RY (t ha $\left.{ }^{-1}\right)$ \\
\hline CNPH 980 & $7 \mathrm{a}$ & $7 b$ & $7 \mathrm{a}$ & $7 a$ & $6 b$ & $9 \mathrm{a}$ & $1 \mathrm{c}$ & $3 b$ & $5 a$ & $5 b$ & $21.9 \mathrm{e}$ & $38.7 \mathrm{c}$ \\
\hline CNPH1205 & $7 \mathrm{a}$ & $3 c$ & $1 \mathrm{c}$ & $3 c$ & $1 d$ & $2 d$ & $3 b$ & $5 a$ & $1 \mathrm{c}$ & $4 c$ & $170.8 \mathrm{a}$ & $89.2 b$ \\
\hline CNPH 895 & $7 \mathrm{a}$ & $5 b$ & $6 b$ & $5 b$ & $3 c$ & $4 c$ & $1 \mathrm{c}$ & $5 a$ & $1 \mathrm{c}$ & $6 a$ & $32.7 \mathrm{c}$ & $121.4 \mathrm{a}$ \\
\hline CNPH 796 & $7 \mathrm{a}$ & $3 c$ & $7 \mathrm{a}$ & $1 d$ & $3 c$ & $2 d$ & $3 b$ & $3 b$ & $1 \mathrm{c}$ & $3 d$ & $35.4 b$ & $30.8 \mathrm{~d}$ \\
\hline CNPH 1284 & $7 \mathrm{a}$ & $9 a$ & $7 a$ & $7 \mathrm{a}$ & $7 \mathrm{a}$ & $6 b$ & $9 \mathrm{a}$ & $3 b$ & $3 b$ & $7 \mathrm{a}$ & $29.2 \mathrm{~d}$ & $28.1 \mathrm{e}$ \\
\hline General Mean & 7.0 & 5.4 & 5.6 & 4.6 & 4.0 & 4.6 & 5.0 & 3.8 & 2.4 & 5.0 & 58.0 & 61.7 \\
\hline $\mathrm{CV}(\%)$ & 4.9 & 9.1 & 8.2 & 11.7 & 9.2 & 8.3 & 8.4 & 10.9 & 15.2 & 7.3 & 0.27 & 0.32 \\
\hline
\end{tabular}

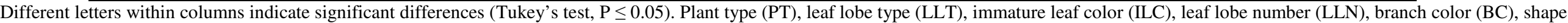
of central leaf lobe (SCLL), petiole pigmentation (PP), mature leaf size (MLS), mature leaf color (MLC), leaf shape (LS), branch yield (BY), and root yield (RY). 
CNPH 980 and CNPH 1284 recorded the highest leaf lobe number, both with seven lobes per leaf, followed by CNPH 895, CNPH 1205, and CNPH 796, with five, three, and one lobe per leaf, respectively (table 1). Leaf lobe number is a trait of easy identification and good differentiation. In this study, accessions CNPH 980 and CNPH 1284 stood out for this particular ornamental trait and were possibly more appreciated by the evaluators due to the unusual shape conferred by the number of lobes per leaf (table 2).

Table 2. Mean of the scores attributed to traits of ornamental interest of five accessions of sweet potatoes from the Germplasm Bank of Embrapa Hortaliças. Brasília - DF, Brazil, 2017.

\begin{tabular}{lcccccccccccc}
\hline Acession & \multicolumn{10}{c}{ Sum of the scores given by each evaluator } \\
\hline & 1 & 2 & 3 & 4 & 5 & 6 & 7 & 8 & 9 & 10 & Mean \\
\hline CNPH 980 & 90 & 85 & 90 & 95 & 60 & 50 & 50 & 30 & 100 & 80 & 73 a \\
CNPH 1205 & 85 & 70 & 50 & 50 & 90 & 50 & 60 & 50 & 60 & 100 & $70 \mathrm{a}$ \\
CNPH 895 & 80 & 87 & 80 & 80 & 60 & 50 & 90 & 80 & 100 & 85 & $79 \mathrm{a}$ \\
CNPH 796 & 85 & 65 & 85 & 60 & 100 & 50 & 60 & 40 & 90 & 70 & $70 \mathrm{a}$ \\
CNPH 1284 & 87 & 80 & 87 & 90 & 50 & 50 & 99 & 100 & 100 & 80 & $82 \mathrm{a}$ \\
\hline
\end{tabular}

Means followed by the same letter, in the columns, do not differ by the Tukey's test ( $\mathrm{p} \leq 0.05)$.

Regarding the shape of central leaf lobe, CNPH 895 and CNPH 796 were classified as triangular; CNPH 1284, as lanceolate; CNPH 980, as linear (narrow); and CNPH 895, as semi-elliptic (table 2). Leaf shape presented the greatest variability within the evaluated traits, and all accessions showed distinct classifications. CNPH 980 had hastate leaf shape, while CNPH 1205, CNPH 895, CNPH 796, and CNPH 1284 presented triangular, lobed, cordate, and almost divided leaf shape, respectively (table 1). Similar results were reported by Villagra et al. (2011), who stated that leaf shape is one of the most important traits for genotypic distinction. Based on Tognon et al. (2015), the leaf shape is one of the most relevant elements in arrangements composition since it gives the idea of movement, transmits smoothness (rounded leaves), or even demonstrates aggressiveness (pointy leaves). Leaf size is equally significant in floral arrangements. CNPH 980, CNPH 796, and CNPH 1284 presented small mature leaf size (leaf length $<8 \mathrm{~cm}$ ). Conversely, $\mathrm{CNPH}$
1205 and CNPH 895 showed medium mature leaf size $(8 \leq$ leaf length $\leq 15 \mathrm{~cm})$ (table 1$)$.

Total root yield ranged from $28.1 \mathrm{t} \mathrm{ha}^{-1}$ (CNPH 1284) to $121.4 \mathrm{t} \mathrm{ha}^{-1}$ (CNPH 895). CNPH 1205 stood out for presenting the highest branch yield $\left(170.8 \mathrm{t} \mathrm{ha}^{-1}\right)$ and considerable root yield of $89.2 \mathrm{t} \mathrm{ha}^{-1}$ (table 1). High branch yield is a desirable trait for branch usage in floral arrangements. In this context, the selection of accessions with higher branch and root yields could be a strategy to add value to the production.

The existing genetic variability among the accessions was expressed by heterogeneity observed in all traits evaluated (fig. 1). The presence of genetic variability is of great interest since it increases ornamentation usage options (TOGNON, 2015). Additionally, Pietro et al. (2012) reported that the green coloration of the species promotes certain lightness to the arrangement. Consequently, ornamental sweet potatoes can add value to the environment making it more attractive, mainly due to the different leaf shapes and distinct color shades (figure 1).
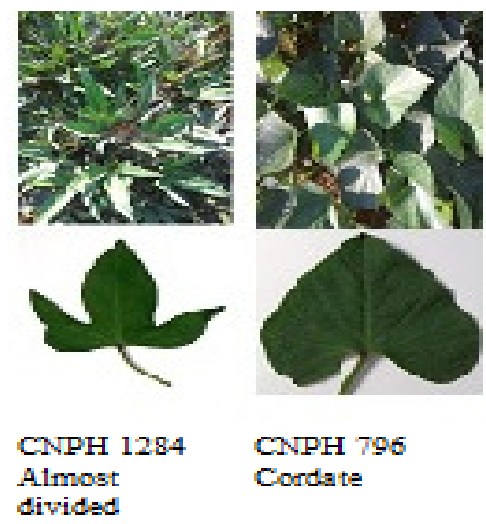

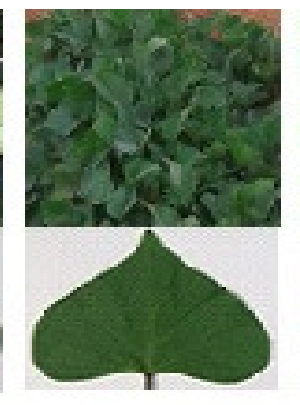

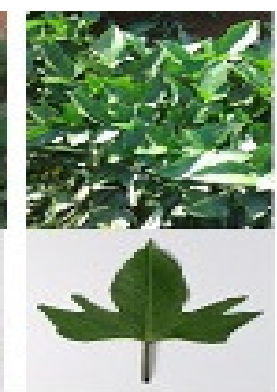

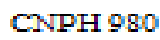

Hastate

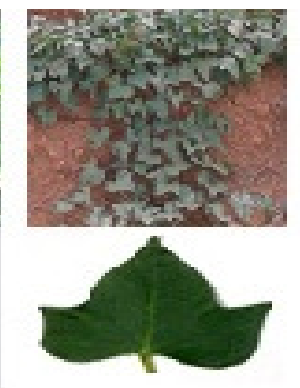

CNPH 895 Lobed

Figure 1. Leaf shape and leaf color of sweet potato (Ipomoea batatas (L.) Lam.). 
The mean scores of the traits of ornamental interest were higher than 70 points for all the accessions evaluated, indicating a high ornamental potential (table 2).

CNPH 1284 presented the greatest score, which means that this accession pleased the evaluators the most. This result could probably be explained by the pleasing appearance of the almost divided leaf shape of CNPH 1284. This accession presented the most harmonious aesthetics, demonstrating a great ornamental potential for the consumer market, according to the evaluators. Although no statistical difference was observed among accessions, CNPH 1284 (almost divided leaf shape) and CNPH 895 (lobular leaf shape) presented $17 \%$ and $13 \%$, respectively, higher scores than the lowest graded accessions (table 2, figure 1).

Ornamental plants are distinguished by their flowering, leaf shape, leaf color, or the overall plant appearance (JANICK, 2006). In recent years, the use of native plants in ecological landscaping has been reported as a trend (HEIDEN et al., 2006). In this context, the sweet potato accessions evaluated in this study demonstrated great morphologic variability and suitability for ornamental purposes. Since they present desirable ornamental characteristics, such as distinct leaf size and colors, these accessions could be used as potted plants, cutting foliage, a complement to table arrangements, or in garden beds.

\section{CONCLUSION}

The present results revealed noticeable morphological differences among the studied accessions. CNPH 1284 stood out for its almost divided leaf type and was considered as the accession with the most harmonious aesthetic. However, all accessions demonstrated high ornamental potential and therefore are suitable to be cultivated as potted plants and/or in garden beds.

\section{ACKNOWLEDGMENT}

To CAPES (Coordination for the Improvement of Higher Education Personnel), for the financial support with scholarships.

RESUMO: A batata-doce [Ipomoea batatas (L.) Lam.] é uma planta com diferentes aptidões de uso das suas raízes, folhas e hastes. O objetivo deste trabalho foi avaliar o potencial ornamental de acessos de batata-doce oriundas do banco de germoplasma mantidos na Embrapa Hortaliças, Brasília, DF, Brasil. Para a caracterização morfológica e avaliação do potencial ornamental, foram escolhidos cinco acessos com formatos de folhas diferentes (CNPH 980, CNPH 1205, CNPH 895, CNPH 796, CNPH 1284) e utilizados doze descritores qualitativos e quantitativos [tipo de planta (TP), tipo de lóbulo da folha (TLF), cor da folha imatura (CFI), número de lóbulos por folha (NLF), cor das ramas (CR), formato do lóbulo central (FLC), pigmento no pecíolo (PP), tamanho da folha madura (TFM), cor da folha madura (CFM), formato da folha (FF), produção de ramas (BY) e produção de raízes (RY)]. Na avaliação do potencial ornamental, cada critério foi pontuado por meio de notas variando de 10 (mínimo) a 100 (máximo). A característica número de lóbulos da folha foi a que mais agradou os avaliadores. Observou-se que quanto mais lóbulos, maior o potencial ornamental, sendo que os acessos CNPH 980, CNPH 1205 e CNPH 1284 se destacaram para essa característica. CNPH 1284, com folhas no formato quase dividido, obteve a maior nota e foi considerado como o acesso com a estética mais harmoniosa, indicando grande potencial ornamental para o mercado consumidor, na opinião dos avaliadores. Os cinco acessos estudados apresentaram considerável potencial ornamental, podendo ser usados como forragem, complementos para arranjos florais ou como jardineiras.

PALAVRAS-CHAVE: Ipomoea batatas (L.) Lam. Descritores morfológicos. Folhas de batata-doce. Banco de germoplasma. Paisagismo.

\section{REFERENCES}

BACHMAN, G. W. E. Ornamental Sweet Potato Response to Bonzi and Sumagic. SNA Research Conference, v. 48. 2003.

FISCHER, S. Z.; BARBIERI, R. L. Abóboras ornamentais: atributos valorizados por consumidor finais e decoradores florais. Horticultura Brasileira, v. 33, n. 4, p. 480-487. 2015. http://dx.doi.org/10. 1590/S0102053620150000400012 . 
HALL, M. R.; PHATAK, S. C. Sweet potato Ipomoea batatas (L.) Lam. In: Kalloo, G., Bergh, B.O. Genetic improvement of vegetable crops, v. 1. Pergamon Press. New York. 1993. 15p.

HALCOMB, J.; TOLBERT, D. M.; JAIN, S. K. A diversity analysis of genetic resources in rice. Euphytica, v. 26, n. 1, p 441-450. 1977.

HEIDEN. G.; BARBIERI, R. L.; STUMPF, E. R. T. Considerações sobre o uso de plantas ornamentais nativas. Revista Brasileira de Horticultura Ornamental, v. 12, n. 1, p. 2-7. 2006.

HUAMÁN, Z. Descriptors for sweet potato. Rome: International Board for Genetic Resources/Centro Internacional de la Papa/Asian Vegetable Research and Development Center. 1991. 134p.

HUAMÁN, Z. Morphologic identification of duplicates in collections of Ipomoea batatas. Lima: International Potato Center. 1992. 28p.

JANICK, J.; PARIS H. S. The Cucurbit images of the Villa Farnesina. Annals of Botany, v. 97, n. 1, p. 165176. 2006. http://dx.doi $10.1093 / \mathrm{aob} / \mathrm{mcj} 025$

JUNQUEIRA, A. H.; PEETZ, M. S. Mercado interno para os produtos da floricultura brasileira: características, tendências e importância socioeconômica recente. Revista Brasileira de Horticultura Ornamental, São Paulo, v. 14, n. 1, p. 37-52. 2011.

OLIVEIRA, A. A. P.; BRAINER, M. S. C. P. Floricultura: caracterização e mercado. Fortaleza. Banco do Nordeste do Brasil. 2007. 180 p.

PIETRO, J.; MATTIUZ, B. H.; MATTIUZ, C. F. M.; RODRIGUES, T. J. D. Manutenção da qualidade de rosas cortadas. Horticultura Brasileira, v. 30, n. 1, p. 64-70. 2012.

SOUZA, A. B. Avaliação de cultivares de batata-doce quanto atributos agronômicos desejáveis. Ciência Agrotécnica, v. 24, n. 4, p. 841-845, 2000.

STUMPF, E. R. T.; HEIDEN, G.; BARBIERI, R. L.; FISCHER, S. Z.; NEITZKE, R. S.; ZANCHET, B.; GROLLI, P. R. Método para avaliação da potencialidade ornamental de flores e folhagens de corte nativas e não convencionais. Revista Brasileira de Horticultura Ornamental, v. 13, n. 1, p. 143-148. 2007.

SMITH, T. Planning for Spring: Production Guidelines for Four Crops - Osteospermum, Angelonia, Calibrachoa e Ornamental Sweet Potato (Ipomoea batatas). Amherst: University of Massachusetts. 2007.

TOGNON, G. B.; CUQUEL. F. L. Ornamental potential and postharvest of Baccharis uncinella D. C. Acta Horticultura, v. 1060, n. 1, p. 133-139, 2015. http://dx.doi.org/10.1590/0103-8478cr20150392

VILLAGRA, B. L. P.; ROMANIUC, N. S. Plantas trepadeiras do Parque Estadual das Fontes do Ipiranga São Paulo, Brasil. Hoehnea, v. 38, p. 325-384. 2011. 